\title{
NOWE WYZWANIA W GOSPODAROWANIU KAPITAŁEM LUDZKIM
}

We współczesnym świecie coraz istotniejszym czynnikiem rozwoju staje się jakość kapitału ludzkiego i odpowiednie gospodarowanie nim na rynku pracy. Ponadto kwestią kluczową dla rozwoju funkcji personalnej jest dobra znajomość trendów rynkowych, obserwowanie działań realizowanych przez inne organizacje oraz wdrażanie nowych rozwiązań zwiększających poziom usług oferowanych w ramach funkcji zarządzania zasobami ludzkimi (ZZL).

Postępująca globalizacja i zmienność otoczenia biznesu zmusza firmy do działań zwiększających ich efektywność ekonomiczną i zdolność uzyskiwania przewag konkurencyjnych. Regulacje prawne pozwalają lokować firmy w krajach, gdzie koszty prowadzenia działalności są niskie, a postęp technologiczny umożliwia sprzedaż produktów i usług tam, gdzie jest na nie popyt. Z jednej strony sprawia to, iż rynkiem zbytu dla przedsiębiorstwa może być niemal cały świat, $z$ drugiej jednak poszerza krąg potencjalnych konkurentów o ogromną liczbę podmiotów z różnych kontynentów. Wynika stąd imperatyw wzrostu efektywności, elastyczności i kreatywności pracowników.

Waga tego imperatywu jest szczególnie duża w przypadku naszego kraju. Po pierwsze dlatego, że poziom rozwoju gospodarczego Polski, w porównaniu z pozostałymi krajami Unii Europejskiej, powoli osiąga tendencję wzrostową. Na przykład polski produkt krajowy brutto (PKB), według parytetu siły nabywczej na 1 mieszkańca (liczony w euro), sięgnął w 2014 r. kwoty 1724,7 mld zł, a w IV kwartale 2014 r. wzrósł o 3,1\%. Skumulowany wzrost Polski od 2007 r. to 23,8\%. To jeden z najlepszych wyników w Europie. Natomiast relatywnie na niskim poziomie pozostaje w Polsce wydajność (liczona w euro na 1 godzinę). Stanowiła ona w 2013 r. tylko 55\% średniego jej poziomu w UE-27 ${ }^{1}$. Po drugie, powolny rozwój gospodarczy odbija się niekorzystnie na poziomie życia Polaków. W Polsce średnie wynagrodzenie

1 Za: www.stat.gov.pl [dostęp: 2.06.2015]. 
brutto na 1 przepracowaną godzinę, liczone w euro, stanowi zaledwie $36,8 \%{ }^{2}$. Po trzecie, wykwalifikowane zasoby ludzkie stanowią główny czynnik kreowania globalnego bogactwa, tymczasem w Raporcie Komisji Europejskiej European Scoreboard 2009 Polska została sklasyfikowana w grupie tzw. umiarkowanych innowatorów. Za silną stronę Polski uznano inwestycje w zasoby ludzkie (miejsce $z$ wynikiem powyżej średniej UE-27) ${ }^{3}$. Po czwarte, w latach 2014-2050, prognozowany jest spadek udziału ludności w wieku produkcyjnym, choć na tle krajów Unii Europejskiej Polska jest nadal krajem stosunkowo młodym. Według danych Eurostatu, mediana wieku populacji Polski w 2012 r. wyniosła 38,7 lat, podczas gdy wskaźnik ten dla krajów członkowskich Unii Europejskiej razem osiągnął wartość 41,9 lat (współczynnik obciążenia demograficznego dla Polski wynosił 20,1, zaś dla UE - 27,5). Jednak zaniechanie działań i niepodjęcie wyzwań, jakie stawia demografia, prowadzi do nieodwracalnych zniekształceń struktury populacji. Jak wskazuje prognoza Eurostatu (EuroPop2013), po 2024 r. udział osób w wieku 65 lat i więcej w strukturze ludności Polski ogółem przekroczy $20 \%$, zaś po 2060 r. - 33\%. Według prognozy GUS w 2050 r., w porównaniu z rokiem 2007, odsetek osób w wieku do 17 roku życia spadnie o prawie $1 / 4$ (do 75,2\%), a osób w wieku $18-44$ lat do $71 \%$. Natomiast wzrośnie udział osób w wieku 45-59/64 do 106,8\%, a osób w wieku poprodukcyjnym $(60+/ 65+)$ aż do $158,2 \%$ w porównaniu do stanu z 2007 r. Oznacza to, że znacznie mniejsza liczba osób w wieku produkcyjnym będzie musiała pracować na utrzymanie nie tylko swoje i swoich rodzin, ale też na zdecydowanie większą liczbę osób w wieku poprodukcyjnym ${ }^{4}$.

Zarówno przyspieszenie tempa wzrostu gospodarczego i związany z tym wymóg wzrostu wydajności i kreatywności pracowników, jak też wydatnej poprawy poziomu życia ludności, stanowią wielkie wyzwanie i wymuszają nowe działania w zakresie ZZL oraz przemiany w zakresie dotychczas realizowanych funkcji personalnych organizacji. W efekcie kapitał ludzki stanowi główne aktywa przedsiębiorstw i staje się nadrzędnym czynnikiem decydującym o przewadze konkurencyjnej na rynku. Aleksy Pocztowski sugeruje, że organizacje, chcąc sprostać wyzwaniom, powinny sięgać po czynniki takie jak: tempo działania, elastyczność, zdolność szybkiego uczenia się i wysokie kompetencje pracowników5.

Koncepcja pracownika jako najważniejszego aktywa organizacji jest obecnie bardzo rozpowszechniona zarówno w literaturze, dzięki rozwojowi nauk o zarządzaniu, jak i w praktyce zarządzania poprzez nową rolę kapitału ludzkiego, wynikają-

2 M. Kabaj, Wpływ systemów kształcenia zawodowego na zatrudnienie i bezrobocie młodzieży. Projekt wdrożenia dualnego systemu kształcenia zawodowego w Polsce, IPiSS, Warszawa 2012, s. 15.

3 European Innovation Scoreboard, European Union, Bruxelles 2010.

4 GUS, Prognoza ludności na lata 2014-2050, Warszawa 2014.

5 A. Pocztowski, Zarządzanie zasobami ludzkimi. Strategie - procesy - metody, Polskie Wydawnictwo Ekonomiczne, Warszawa 2007, s. 38. 
cą z przekształcenia gospodarki w kierunku gospodarki opartej na wiedzy. Pozycja przedsiębiorstwa funkcjonującego w warunkach gospodarki opartej na wiedzy w coraz większym zakresie zależy od jakości jego zasobów niematerialnych, czyli kapitału ludzkiego. W nowej gospodarce rozwój gospodarczy, jak i wzrost wartości przedsiębiorstw, zależy głównie od wiedzy pracowniczej i jej wykorzystania. Organizacje czerpią głównie z intelektu i wiedzy pracowników, a więc coraz częściej w zarządzaniu stosują kompleksowe podejście oparte na kompetencjach. Współczesne organizacje są zatem zmuszone do poszukiwania narzędzi umożliwiających im właściwe diagnozowanie, ocenianie i rozwijanie kompetencji pracowników, gdyż to właśnie wiedza pracowników stanowi w dużej mierze o przewadze konkurencyjnej firmy. Pozycję lidera rynku będzie się zatem osiągać nie dzięki posiadanym zasobom fizycznym czy finansowym, lecz dzięki potencjałowi tkwiącemu w kapitale ludzkim ${ }^{6}$.

Jak zauważa Stanisława Borkowska, w erze gospodarki napędzanej wiedzą treść pracy ludzkiej oraz miejsce, czas, metody i narzędzia jej realizacji, ulegają bardzo szybkim zmianom. Można dostrzec, że w minionym stuleciu nastąpiła wielka ewolucja:

1. Od dominacji pracy fizycznej do dominacji pracy opartej na wiedzy (dominacji pojmowanej nie w wymiarze ilościowym, ile wpływu na wartość organizacji i jej zdolność uzyskiwania przewagi konkurencyjnej na globalnych rynkach);

2. Od pracy prostej, rutynowej do pracy kreatywnej, zmiennej i zdywersyfikowanej (a w ślad za tym rozwojem kultury uczenia się, otwartości na zmiany, kreatywności, a także kultury akceptacji niepewności, ryzyka i wielokulturowości);

3. Od przedmiotowego do podmiotowego traktowania pracownika (upełnomocnienia, wzrostu samodzielności i odpowiedzialności);

4. Od pracy indywidualnej i opartej na rywalizacji do pracy grupowej i opartej na współpracy oraz otwartej komunikacji;

5. Od pracy nieobjętej żadną ochroną prawną poprzez pracę opartą na kontrakcie psychologicznym ${ }^{7}$.

Na tym tle warto podkreślić współwystępowanie różnych form i metod realizacji funkcji personalnych i ich ewolucji. Dotyczy to głównie doboru kandydatów do zatrudnienia, utrzymywania pracowników w organizacji poprzez ich motywowanie z odpowiednim uwzględnieniem cech rynku pracy, a także rozwoju pracowników, m.in. przez kształtowanie kompetencji przydatnych do realizacji misji, strategii, celów i zadań organizacji, według subiektywnych preferencji jej kierownictwa. Niezależnie jednak od kontekstu, determinującego praktyki ukierunkowane na racjonalne

6 J.R. Perez, P. Ordonez de Pablos, Knowledge Management and Organizational Competitiveness. A Framework for Fuman Capital Analysis, „Journal of Knowledge Management” 2003, vol. 7 , no 3, s. 82; za: M.W. Staniewski, Zarządzanie zasobami ludzkimi a zarządzanie wiedzą w przedsiębiorstwie, VIZJA PRESS \& IT, Warszawa 2008, s. 17.

7 S. Borkowska, W sprawie tożsamości zzl, [w:] S. Borkowska (red.), Zarządzanie zasobami ludzkimi w Polsce. Przeszłość, teraźniejszość, przyszłość, Oficyna a Wolters Kluwer business, Kraków 2007, s. 239-240. 
wykorzystanie człowieka w organizacji, ich istotą było, jest i prawdopodobnie będzie panowanie nad zdolnością pracowników do realizacji celów i zadań organizacji ${ }^{8}$.

Zdzisława Janowska proponuje odnieść się do strategii rozwoju Polska 2030, w której wśród kluczowych wyzwań przyszłości znajduje się głównie rozwój zasobów ludzkich, dzięki kształceniu ustawicznemu oraz pełnemu wykorzystaniu kwalifikacji pracowniczych ${ }^{9}$.

Wartą odnotowania jest lista najważniejszych wyzwań ZZL opartego na kompetencjach, autorstwa Tadeusza Oleksyna:

- zapewnienie niezbędnych kompetencji - ludziom, organizacjom i całemu społeczeństwu - gwarantujących wysoką jakość pracy i życia;

- osiąganie wysokiego poziomu efektywności i konkurencyjności;

- zapewnienie i rozwijanie zdolności ludzi do wykonywania pracy zawodowej, a przez to umożliwienie im samorealizacji, utrzymania siebie i swoich rodzin oraz godziwej egzystencji we wszystkich wymiarach życia;

- dostosowanie kompetencji do zmieniających się potrzeb, co wymaga uzupełniania kwalifikacji, a niekiedy przekwalifikowania, zmian miejsc pracy i treści ról organizacyjnych, a także niezbędnej elastyczności ${ }^{10}$.

W kontekście zmian w ZZL A. Pocztowski proponuje pięciofazowy model architektury zasobów ludzkich (human resources, HR) ${ }^{11}$. Znajomość zewnętrznych uwarunkowań biznesowych jako pierwsza faza modelu bezwzględnie wymaga posiadania wyspecjalizowanych pracowników w działach zarządzania zasobami ludzkimi, odpowiednio adaptujących praktyczne rozwiązania w procesie zarządzania ludźmi. Druga faza, związana z dostarczaniem usług zewnętrznym i wewnętrznym interesariuszom, oscyluje wokół tworzenia wartości dla inwestorów poprzez wzrost aktywów niematerialnych, zwiększania udziału w rynku poprzez relacje z klientami, wspierania menedżerów liniowych w realizacji strategii oraz dostarczania wartości pracownikom i rozwijania ich zdolności. W kolejnej fazie następuje doskonalenie praktyk HR poprzez poprawę efektywności pracy, zarządzanie informacjami, projektowanie procesów pracy w sposób tworzący wartość. Czwarta faza modelu HR odnosi się do tworzenia strategii i struktury personalnej jako narzędzi tworzenia wartości, poprzez dostosowanie formy organizacyjnej funkcji personalnej do strategii przedsiębiorstwa oraz praktykowanie planowania strategicznego w celu dostosowania inwestycji w zasoby

8 J. Szmbelańczyk, Kontrowersje wokół naukowej tożsamości zarządzania zasobami ludzkimi, [w:] S. Borkowska (red.), Zarządzanie zasobami..., s. 261.

9 Z. Janowska, Zarządzanie zasobami ludzkimi, Polskie Wydawnictwo Ekonomiczne, Warszawa 2010, s. 263.

10 T. Oleksyn, Zarządzanie kompetencjami. Teoria i praktyka, Oficyna a Wolters Kluwer business, Warszawa 2010, s. 40.

11 A. Pocztowski, Zarządzanie zasobami ludzkimi. Strategie..., s. 82; I. Kołodziejczyk-Olczak, Zarządzanie pracownikami w dojrzałym wieku, Wydawnictwo Uniwersytetu Łódzkiego, Łódź 2014, s. 31 . 
ludzkie do celów przedsiębiorstwa. Ostatnia faza zwraca uwagę na profesjonalizm funkcji personalnej, poprzez ciągły rozwój i doskonalenie specjalistycznych kompetencji osób zajmujących się zarządzaniem zasobami ludzkimi.

Jak widać, wyzwania oraz kierunki stawiane współcześnie zarządzaniu zasobami ludzkimi są wyjątkowo złożone i wygórowane.

Dla wszystkich firm, niezależnie od wielkości i rodzaju działalności, przyciągnięcie, utrzymanie i rozwój kompetentnych pracowników stanowi istotny problem. Zmianie podlegają procesy zarządzania zasobami ludzkimi, których podstawą coraz częściej jest tworzenie relacji z pracownikami opartych na zaufaniu, wzajemności oraz tworzeniu możliwości rozwoju w ramach organizacji. Jak zatem sprawić, by organizacja przyciągała i zatrzymywała najlepszych pracowników, którzy pozwolą jej rozwijać się na tak wymagającym globalnym rynku? Odpowiedzi na to pytanie szuka gospodarowanie kapitałem ludzkim, czyli koncepcja, która stara się połączyć ekonomiczny punkt widzenia, zorientowany na wynik finansowy i zwrot z inwestycji, z odpowiedzialnością społeczną kładącą nacisk na samorealizację i satysfakcję pracowników. Jest to trudne zadanie, zwłaszcza w świetle wyzwań, które stawiają współczesne czasy. Fuzje i przejęcia, przenoszenie firm w obszary tańszej produkcji leżące poza krajem macierzystym, restrukturyzacje oraz upadłości - wszystkie te zjawiska składają się na poczucie niepewności dotyczące przyszłości zatrudnienia oraz bytu organizacji. Z drugiej strony, pracownicy nie są już przywiązani do konkretnych przedsiębiorstw i bez większych rozterek zmieniają pracę, jeśli gdzie indziej znajdą ciekawsze projekty, wyższe wynagrodzenie lub lepsze szanse rozwoju.

Jak w tych warunkach budować zaangażowanie i lojalność pracowników? Jak oceniać pracowników, wiązać wynagrodzenie z efektami pracy, diagnozować i niwelować potrzeby szkoleniowe? Jak wyglądają obecnie przepisy prawa pracy i innych aktów regulujących formy zatrudnienia czy też, szerzej ujmując, związki organizacji z jej członkami? Czy regulacje te nadążają za stanem faktycznym? Na te i pokrewne pytania stara się dać odpowiedź publikacja „Gospodarowanie kapitałem ludzkim - wyzwania organizacyjne i prawne”, która przyjmuje podejście interdyscyplinarne, gdyż tylko wielość punktów widzenia pozwala uzyskać możliwie szeroki obraz tak złożonego zjawiska, jakim są współczesne wyzwania gospodarowania kapitałem ludzkim.

Niniejsza monografia została przygotowana przez autorów będących członkami Studenckiego Koła Naukowego Human Resources Management, istniejącego przy Katedrze Pracy i Polityki Społecznej Uniwersytetu Łódzkiego oraz wyróżniających się interesującymi wystąpieniami uczestników I Ogólnopolskiej Konferencji Naukowej pt. „Gospodarowanie kapitałem ludzkim - wyzwania organizacyjne i prawne”, zorganizowanej przez Koło Naukowe HRM w listopadzie 2014 r. Jest to kolejna, piąta z kolei, publikacja opracowana przez SKN HRM dotycząca szerokiej tematyki kapitału ludzkiego na rynku pracy. 
Pierwszą publikacją związaną z tym zagadnieniem była monografia, która ukazała się pod redakcją Anny Rogozińskiej-Pawełczyk i Dominika Majewskiego w 2010 roku, pt. „Dobry start kariery zawodowej”. Jej celem było skierowanie do ludzi młodych praktycznych wskazówek z zakresu wiedzy na temat zatrudnienia, zakładania i prowadzenia działalności gospodarczej oraz procesu poszukiwania i doboru pracowników. Wielkim sukcesem książki było wyróżnienie w kategorii „Publikacja roku 2011”, w konkursie Studenckiego Ruchu Naukowego „StRuNa 2011”, odbywającym się pod patronatem honorowym ówczesnej Minister Nauki i Szkolnictwa Wyższego, profesor Barbary Kudryckiej.

Kolejną monografią z nurtu poradnikowego, która stała się pomocą dla osób wchodzących na rynek pracy i tam rozpoczynających własną karierę zawodową była publikacja pt. „Absolwent na rynku pracy”. Wydana została w 2011 roku, pod tą samą redakcją, również nakładem Wydawnictwa Uniwersytetu Łódzkiego.

Trzecią książką opublikowaną w 2013 w ramach pracy zespołowej Studenckiego Koła Naukowego „HRM” była publikacja pt. „Trendy na rynku pracy”. W tej monografii autorzy skupili się głównie na wskazaniu tendencji występujących na polskim rynku pracy, jak i w krajach europejskich. Zaproponowali podjęcie konkretnych kierunków działań i rozwiązań w celu poprawy sytuacji na rynku pracy głównie ludzi młodych, absolwentów studiów wyższych.

Następną w kolejności, wydaną w 2014 roku, monografią naukową była publikacja pt. „Pokolenia na rynku pracy” pod redakcją Anny Rogozińskiej-Pawełczyk. Książka ma charakter wielowątkowy, a jej tematyka oscyluje wokół problematyki współczesnego rynku pracy i zatrudnienia, w kontekście podziałów pokoleniowych. Można w niej odnaleźć opracowania monograficzne poszczególnych generacji uczestników rynku bądź grup wyróżnionych w oparciu o inne kryteria (np. osoby niepełnosprawne).

Studenckie Koło Naukowe Human Resources Management od 2004 roku działa przy Katedrze Pracy i Polityki Społecznej Wydziału Ekonomiczno-Socjologicznego Uniwersytetu Łódzkiego. Działalność naukowa Koła skupia się wokół problematyki zarządzania zasobami ludzkimi, kładąc szczególny nacisk na naukę poprzez praktykę. Koło HRM rozwinęło swoją działalność przede wszystkim poprzez cykliczne spotkania z pracownikami UŁ oraz praktykami, specjalistami z zakresu zarządzania zasobami ludzkimi, na których omawiane są różne problemy z zakresu gospodarowania kapitałem ludzkim w nowoczesnych organizacjach. Członkowie SKN HRM organizują wiele wydarzeń naukowych, kulturalnych czy też społecznych oraz przygotowują i uczestniczą w konferencjach, a także publikują artykuły, czego wyrazem są wspomniane wyżej monografie naukowe.

Kolejnym sukcesem Koła jest wydawanie od trzech lat w wersji elektronicznej magazynu studenckiego pt. „HR Gear”. Periodyk ten to pierwsze na Wydziale Ekonomiczno-Socjologicznym czasopismo (kwartalnik) skupiające się wokół zagadnień z zakresu zarządzania zasobami ludzkimi i obszaru rynku pracy. Autorami artyku- 
tów są studenci, doktoranci oraz osoby, które zawodowo zajmują się HR-em. Celem magazynu jest rozpowszechnianie wiedzy dotyczącej szeroko pojętego rynku pracy wśród studentów Uniwersytetu Łódzkiego.

Dzięki inspiracji opiekuna naukowego, dr Rogozińskiej-Pawełczyk, SKN HRM od ośmiu już lat cyklicznie organizuje obozy naukowe. Ich celem jest poznanie przez studentów praktycznych wskazówek przydatnych podczas prezentacji, rozmowy kwalifikacyjnej, pisania CV i listów motywacyjnych, a także wybranych aspektów prawa pracy i umiejętności zarządzania własną karierą zawodową. Obozy są także platformą wymiany poglądów, idei i doświadczeń, jak również konfrontacją teorii z praktyką. Po obozach powstają publikacje naukowe, poświęcone zagadnieniom związanym z rynkiem pracy oraz ze startem w karierę absolwentów szkół wyższych. Uczestnikami obozu są przede wszystkim studenci Uniwersytetu Łódzkiego, zaproszeni przedstawiciele firm działających na terenie miasta Łodzi, członkowie Koła, jak również pracownicy Katedry Pracy i Polityki Społecznej. Do tej pory zorganizowano następujące obozy naukowe: 1) 11-13 kwietnia 2008 Grotniki k. Łodzi, tematyka „Przygotowanie studentów do wejścia na rynek pracy - jak się skutecznie wypromować?"; 2) 3-5 kwietnia 2009 r., Rawa Mazowiecka, temat „Team building - efektywne sposoby motywowania"; cyklicznie, pod tytułem „Dobry start kariery zawodowej”, w Rawie Mazowieckiej zorganizowano sześć obozów naukowych.

Pomysłem, który narodził się i został zrealizowany w 2015 roku było zorganizowanie I Obozu Naukowego dla Członków SKN HRM pt. „Ostrzenie piły, rozwój kompetencji ogólnych i profesjonalnych". Od tej pory, co roku, aktywni i wyróżniający się członkowie Koła będą mieli możliwość doskonalenia swoich kompetencji poprzez dwudniową sesję coachingową ze specjalistą - praktykiem i trenerem biznesu w tej dziedzinie.

Redaktorem naukowym wszystkich powyżej wspomnianych monografii oraz niniejszej publikacji "Gospodarowanie kapitałem ludzkim - Wyzwania Organizacyjne i Prawne" jest dr Anna Rogozińska-Pawełczyk. Piastuje ona stanowisko adiunkta w Katedrze Pracy i Polityki Społecznej Uniwersytetu Łódzkiego oraz w Zakładzie Zarządzania Zasobami Ludzkimi w Instytucie Pracy i Spraw Socjalnych w Warszawie. Od 2006 roku pełni funkcję opiekuna naukowego SKN „HRM”, gdzie koordynuje organizację działalności Koła. Dr Rogozińska-Pawełczyk jest ponadto ekspertem zewnętrznym, koordynatorem oraz realizatorem kilku projektów badawczych Narodowego Centrum Nauki oraz projektów finansowanych ze środków Europejskiego Funduszu Społecznego. Jest również autorką i współautorką kilkudziesięciu publikacji z zakresu Human Resources Management, High Performance Work Systems, Work Life Balance oraz Psychological Contract.

Publikacja „Gospodarowanie kapitałem ludzkim - wyzwania organizacyjne i prawne" podzielona została na dwie części. Pierwsza z nich oscyluje wokół zagadnień związanych z zarządzaniem zasobami ludzkimi na rynku pracy i w organizacji. Druga część monografii zajmuje się bliższym wyjaśnieniem uwarunkowań gospodarowania kapitałem ludzkim w świetle regulacji Kodeksu pracy. 
Pierwszy rozdział, autorstwa Marii Olejniczak, zatytułowany „Gospodarowanie kapitałem ludzkim w świetle organizacyjno-prawnym. Szanse i zagrożenia”, odwołuje się do wzrostu znaczenia stosunków zatrudnienia we współczesnym świecie. Poruszono tutaj głównie tematykę związaną z elastycznymi, nowoczesnymi formami zatrudnienia pracowników (freelancingiem) z perspektywy zachowań organizacyjnych oraz regulacji stosunków prawnych między pracodawcą a pracownikiem.

„Niepewność zatrudnienia i jej skutki - wybrane ujęcia teoretyczne" to kolejny rozdział przedstawiający wyraźnie negatywne konsekwencje dla jednostek i organizacji wynikające ze zjawiska niepewności zatrudnienia. Autor, Piotr Chojnacki, dokonał przeglądu najpopularniejszych ujęć teoretycznych, wykorzystywanych w światowej literaturze, na temat niepewności zatrudnienia, co może ułatwić dalszy rozwój systematycznych badań na ten temat w Polsce.

W trzecim rozdziale, pt. „Gospodarowanie kapitałem ludzkim w jednostkach samorządu terytorialnego", Ewelina Stasiak skupia uwagę Czytelników na specyfice kierowania i doskonalenia kapitału ludzkiego w jednostkach samorządu terytorialnego. Autorka wymienia elementy sprzyjające profesjonalnemu działaniu organizacji, wśród których wiedza i etyczne postawy urzędników odgrywają coraz większą rolę.

Specyfika uwarunkowań zarządzania kapitałem ludzkim w spółdzielniach socjalnych została interesująco zaprezentowana w czwartym rozdziale przez Michała Sobczaka. Autor wskazuje na samą specyfikę procesu zarządzania zasobami ludzkimi w spółdzielniach socjalnych, która przebiega w odmienny sposób niż w sektorze przedsiębiorstw czy nawet organizacjach pozarządowych. Swoje teoretyczne wywody popiera wynikami badań ankietowych prowadzonych w 42 spółdzielniach socjalnych z województwa łódzkiego.

Kolejny rozdział jest poświęcony prognozie zarządzania wiekiem w latach 20152035. Henryk Wojtaszek, zarysowując skalę procesu starzenia się polskiego społeczeństwa, sugeruje odpowiednie przygotowanie przedsiębiorców do umiejętnego, właściwego zarządzania wiekiem w firmach w najbliższych dwóch dekadach.

Szósty z kolei rozdział, pt. „Gospodarowanie kapitałem ludzkim z uwzględnieniem perspektywy płci", dotyczy analizy regulacji prawnych i rozwiązań funkcjonujących w polskim prawodawstwie, w kontekście uregulowań unijnych oraz międzynarodowych wprowadzanych na rzecz równości płci. Autorka, Wiktoria Domagała, posługując się wynikami badań i rezultatami zrealizowanych projektów, dokonuje analizy praktyk wyrównywania szans kobiet i mężczyzn oraz wdrażania zarządzania różnorodnością w organizacjach.

Pozostając w obszarze gender, kolejny rozdział dedykowany jest kobietom - „Sylwetka kobiet na polskim rynku pracy". Współautorki, Małgorzata Adamczyk i Magdalena Jaszczak, omawiając sytuację na polskim rynku pracy, budują profil kobiety w wieku produkcyjnym (18-67 lat), wskazują na tendencje zmian w strukturze zatrudnienia, możliwości podjęcia pracy i realizacji kariery zawodowej. Prezentują także bariery i stereotypy, z jakimi borykają się kobiety na rodzimym rynku pracy. 
W następnym rozdziale, zatytułowanym „Kreatywne zarządzanie własnym życiem - produktywne gospodarowanie osobistymi zasobami w życiu prywatnym i zawodowym", Katarzyna Rybińska zwraca uwagę na bardzo istotny obecnie temat dotyczący świadomego zarządzania swoim czasem, życiem zawodowym oraz prywatnym. Autorka stara się uświadomić Czytelnikom, jak dzielić sprawy na naprawdę ważne i na takie, które można pominąć. Zachęca do wyrabiania w sobie dobrych nawyków, tak aby mieć kontrolę nad własnym życiem i być z niego zadowolonym, co staje się podstawą produktywnego i harmonijnego gospodarowania własnymi zasobami zarówno w życiu zawodowym, jak i osobistym.

Dziewiąty rozdział, pt. „System motywacji jako kluczowy czynnik kształtowania kapitału ludzkiego", ukazuje czynniki wspomagające kształtowanie zasobów ludzkich poprzez system motywacji. Odpowiednie motywowanie pracowników do pracy sprawia, że wzbudza się w nich poczucie odpowiedzialności za firmę, zapał do pracy i chęć wpływania na jej dobry wizerunek. Ważnym elementem, jaki wskazuje Autorka rozdziału, Aleksandra Strojna, jest też atmosfera pomiędzy pracownikami instytucji.

Ostatni rozdział części pierwszej, „Rola lidera w efektywnym zarządzaniu zespołem projektowym”, autorstwa Pauliny Kopackiej, omawia pożądane umiejętności oraz cechy osobowościowe lidera. W opracowaniu znalazła się charakterystyka efektywnego lidera oraz predyktory produktywnej pracy zespołu projektowego.

Drugą część, związaną z wyzwaniami prawnymi gospodarowania kapitałem ludzkim, otwiera rozdział autorstwa Kamila Miśtala pt. „Kilka uwag o instytucjach rynku pracy". Stanowi ono omówienie podstawowych kwestii związanych z mnogością instrumentów, jakimi dysponują organy zajmujące się pośrednictwem pracy. Należy potraktować to opracowanie jako zbiór rozwiązań instytucjonalnych i prawnych, jakie funkcjonują na polskim gruncie polityki zatrudnienia.

Drugi rozdział, który napisała Aleksandra Pietras, skupia się wokół podnoszenia kwalifikacji zawodowych przez pracowników jako inwestycji w kapitał ludzki w świetle regulacji Kodeksu pracy. Opracowanie w swoim zamyśle ma na celu przybliżyć Czytelnikowi aktualnie obowiązujące regulacje prawne dotyczące problematyki zdobywania, uzupełniania wiedzy i umiejętności przez pracowników oraz prawa i obowiązki stron stosunku pracy wynikające z podnoszeniem kwalifikacji zawodowych przez pracownika.

Kolejny rozdział, pt. „Elastyczne formy zatrudnienia jako element gospodarowania kapitałem ludzkim", stanowi prawną analizę nietypowych form zatrudnienia w kontekście gospodarowania kapitałem ludzkim. Irmina Mirecka przedstawia również wybrane instytucje prawne zaliczane do elastycznych form zatrudnienia. Kładzie nacisk na ukazanie zalet i wad każdej z nich, nie pomijając coraz popularniejszej koncepcji flexicuirity.

W czwartym rozdziale drugiej części, zatytułowanym „Kontrolowana liberalizacja prawa pracy jako koncepcja rozwoju rynku zatrudnienia na przykładzie zatrudnienia pracowników tymczasowych przez agencje pracy tymczasowej", Robert 
Wilczyński podjął rozważania dotyczące wzajemnych relacji pomiędzy doktryną i judykaturą prawa pracy a oczekiwaniami przedsiębiorców w ramach uregulowań prawnych zatrudnienia. W artykule dominuje spojrzenie na zagadnienie rozwoju pracy tymczasowej z punktu widzenia doktryny prawa pracy. Omówiona została rola zatrudnienia tymczasowego $\mathrm{w}$ świetle uregulowań normatywnych tego zjawiska, począwszy od nowelizacji Kodeksu pracy w 2002 roku umożliwiającej powstanie rynku pracy tymczasowej, poprzez uchwalenie w 2003 roku ustawy o zatrudnianiu pracowników tymczasowych, a skończywszy na omówieniu rynku pracy tymczasowej w 2014 roku.

W następnym rozdziale, pt. „Karnoprawna ochrona przed mobbingiem w prawie polskim - uwagi de lege lata i postulaty de lege ferenda", Artur Aleksander Dąbrowski koncentruje się na problematyce odpowiedzialności karnej za działanie lub zachowanie zdefiniowane jako mobbing, w świetle aktualnie obowiązujących przepisów prawa polskiego. Ponadto kładzie nacisk na udzielenie odpowiedzi na pytanie, czy obecny system karnoprawny daje rękojmię efektywnej ochrony przed mobbingiem, czy też wymaga on wprowadzenia ewentualnych nowelizacji, które zminimalizują występowanie sytuacji bezkarności mobbera.

Ostatni rozdział, zamykający monografię, to opracowanie Artura Tima pt. „Zapobieganie podwójnemu opodatkowaniu dochodów z pracy najemnej w kontekście unijnej swobody przepływu pracowników". Stanowi ono asumpt do zarysowania znaczenia swobody przepływu pracowników w krajach UE w powstawaniu zjawiska podwójnego opodatkowania dochodów osiąganych z pracy najemnej. Wskazuje też na mechanizm powstawania i wypracowywania na gruncie międzynarodowego prawa podatkowego metody przeciwdziałającej podwójnemu opodatkowaniu.

Niniejsza książka nie powstałaby, gdyby nie finansowe wsparcie Rektora Uniwersytetu Łódzkiego oraz Dziekanów Wydziału Ekonomiczno-Socjologicznego oraz Wydziału Prawa i Administracji Uniwersytetu Łódzkiego, którym składam szczególne wyrazy wdzięczności.

Oddawana do rąk Czytelników monografia nie jest wszechstronnym ujęciem organizacyjno-prawnym. Zawarte w nim opracowania wzbogacają naszą wiedzę na temat wyzwań gospodarowania kapitałem ludzkim w obydwu obszarach.

Jeśli niniejsza publikacja skłoni Czytelnika, czy wręcz zachęci, do chwili refleksji nad tymi wyzwaniami, to podstawowy cel niniejszego opracowania zostanie osiągnięty, czego sobie i Państwu życzę.

\section{BIBLIOGRAFIA}

Borkowska S. (red.), Zarządzanie zasobami ludzkimi w Polsce. Przeszłość, teraźniejszość, przyszłość, Oficyna a Wolters Kluwer business, Kraków 2007.

European Union, European Innovation Scoreboard, Bruxelles 2010.

GUS, Prognoza ludności na lata 2014-2050, Warszawa 2014. 
Janowska Z., Zarządzanie zasobami ludzkimi, Polskie Wydawnictwo Ekonomiczne, Warszawa 2010.

Kabaj M., Wpływ systemów kształcenia zawodowego na zatrudnienie i bezrobocie młodzieży. Projekt wdrożenia dualnego systemu kształcenia zawodowego w Polsce, IPiSS, Warszawa 2012.

Kołodziejczyk-Olczak I., Zarządzanie pracownikami w dojrzałym wieku, Wydawnictwo Uniwersytetu Łódzkiego, Łódź 2014.

Oleksyn T., Zarządzanie kompetencjami. Teoria i praktyka, Oficyna a Wolters Kluwer business, Warszawa 2010.

Pocztowski A., Zarządzanie zasobami ludzkimi. Strategie - procesy - metody, Polskie Wydawnictwo Ekonomiczne, Warszawa 2007.

Staniewski M.W., Zarządzanie zasobami ludzkimi a zarządzanie wiedzą w przedsiębiorstwie, VIZJA PRESS \& IT, Warszawa 2008.

Źródła internetowe

www.stat.gov.pl 